\title{
Sensitivity of the Amazon biome to high resolution climate change projections
}

\author{
Andre de Arruda LYRA ${ }^{1 *}$, Sin Chan CHOU ${ }^{2}$, Gilvan de Oliveira SAMPAIO ${ }^{1}$ \\ ${ }_{1}$ National Institute for Space Research, Earth System Science Center, Cachoeira Paulista, SP, Brazil \\ ${ }^{2}$ National Institute for Space Research, Center for Weather Forecasts and Climate Studies, Cachoeira Paulista, SP, Brazil \\ * Corresponding author: andre.lyra@cptec.inpe.br
}

\begin{abstract}
:
Despite the reduction in deforestation rate in recent years, the impact of global warming by itself can cause changes in vegetation cover. The objective of this work was to investigate the possible changes on the major Brazilian biome, the Amazon Rainforest, under different climate change scenarios. The dynamic vegetation models may simulate changes in vegetation distribution and the biogeochemical processes due to climate change. Initially, the Inland dynamic vegetation model was forced with initial and boundary conditions provided by CFSR and the Eta regional climate model driven by the historical simulation of HadGEM2-ES. These simulations were validated using the Santarém tower data. In the second part, we assess the impact of a future climate change on the Amazon biome by applying the Inland model forced with regional climate change projections. The projections show that some areas of rainforest in the Amazon region are replaced by deciduous forest type and grassland in RCP4.5 scenario and only by grassland in RCP 8.5 scenario at the end of this century. The model indicates a reduction of approximately $9 \%$ in the area of tropical forest in RCP4.5 scenario and a further reduction in the RCP 8.5 scenario of about $50 \%$ in the eastern region of Amazon. Although the increase of $\mathrm{CO}_{2}$ atmospheric concentration may favour the growth of trees, the projections of Eta-HadGEM2-ES show increase of temperature and reduction of rainfall in the Amazon region, which caused the forest degradation in these simulations.
\end{abstract}

KEYWORDS: climate change, regional climate model, dynamic vegetation model

\section{Sensibilidade da floresta amazônica a projeções de mudanças climáticas de alta resolução}

\section{RESUMO:}

Apesar da redução na taxa de desmatamento nos últimos anos, o impacto do aquecimento global por si só pode causar alteraçôes na cobertura vegetal. O Objetivo deste trabalho foi investigar as possíveis alteraçôes no maior bioma brasileiro, a Floresta Amazônica, levando em consideração diferentes cenários de mudanças climáticas. Os modelos de vegetação dinâmica permitem representar as mudanças na distribuiçáo de vegetaçáo bem como nos processos biogeoquímicos diante de mudanças no clima. Na primeira parte do trabalho, o modelo de vegetação dinâmica Inland foi forçado com condiçóes iniciais e de contorno geradas a partir de dados de reanálise (CFSR) e pela regionalização da simulação histórica de um modelo global do sistema terrestre (HadGEM2-ES) com o modelo Eta. Estas simulaçóes foram validadas utilizando os dados da torre de Santarém-K83. Na segunda parte, avaliou-se o impacto de uma futura mudança climática sobre o bioma floresta através das projeçôes do modelo Inland forçado com um modelo regional climático. As projeções mostram que algumas áreas de floresta tropical na Amazônia são substituídas por tipo de floresta decídua e pastagem natural no cenário RCP4.5 e apenas por pastagem natural no cenário RCP8.5 no final do século XXI. No Estado do Amazonas, o modelo indica uma reduçáo de cerca de $9 \%$ da área de floresta tropical no cenário RCP4.5 e uma redução maior no cenário RCP8.5 de cerca de 50\%. Embora o aumento da concentraçáo de $\mathrm{CO}_{2}$ atmosférico possa favorecer o crescimento das árvores, as projeçóes do modelo Eta-HadGEM2-ES mostram aumento da temperatura e redução da precipitação na região Amazônica, levando a degradação da floresta nestas simulaçóes.

PALAVRAS-CHAVE: mudança climática, modelagem regional, vegetação dinâmica. 


\section{INTRODUCTION}

Climate change may impact directly on vegetation such as water deficit stress, dieback, or increased fire frequency. The combined effects of these factors may impact severely the major biomes in Brazil, such as the Amazon Rainforest and the Cerrado. In addition, global and regional climate models have projected changes in precipitation and enhanced warming over central South America for the next decades (Marengo et al. 2012).

Despite the reduction in deforestation rate in recent years, the impact of global warming by itself can cause changes in vegetation cover. Several studies have sought to identify the response of vegetation due to climatic changes, but the results have not been consistent. Kirschbaum and Fischlin (1996) indicated that an increase in the average surface temperature of about $1{ }^{\circ} \mathrm{C}$ would be sufficient to cause changes in the growth and regeneration capacity of many forest species. Miles et al. (2004) indicated that the species of higher tolerance to environmental variations were less sensitive to changes in the atmospheric concentration of $\mathrm{CO}_{2}$.

It is well agreed that climate change and the occurrence of extreme weather events can alter the composition of species (IPCC 2007) and affect the future sustainability of tropical forests. Salazar et al. (2007) studied the consequences of projected climate change on the biome distribution in South America using a potential vegetation model for two greenhouse gas emission scenarios, A2 and B1. Their results indicated the reduction of tropical forest areas, and the replacement by savanna areas in the worst scenario. The large loss of forest biomass was also projected using more complex vegetation models under increased drying and warming scenarios (Betts et al. 2004; Cox et al. 2004). Hutyra et al. (2005) suggested that the climate variability, drought frequency, and seasonality of soil moisture, in addition to other factors that may interact synergistically as fire, are critical factors for determining forest savanna boundaries and vegetation vulnerability in the Amazon. Some studies tried to find which major factor affects the conversion of the Amazon forest to another biome (Galbraith et al. 2010; Good et al. 2011; Settele et al. 2014). However, the projections are strongly dependent on the model used as future projections of different models show large differences in rainfall over the Amazon at the end of the century.

Projections of climate change derived from regional climate models can be considered useful for studies on climate impacts. Due to the subcontinental pattern and the magnitude of change, a better representation of topography, land use and land-sea mask is required. Therefore, the objective of this study was to investigate the possible changes on the major Brazilian biome, the Amazon Rainforest, under different climate change scenarios.

\section{MATERIALS AND METHODS}

In this study, the dynamic vegetation model Inland (Integrated Model of Land Surface Processes) driven by two representative concentration pathways (RCPs) scenarios was applied to assess long-term interactions between the Amazon biome and climate, and to verify the potential impacts on vegetation cover caused by climate changes and by the increase in the concentration of $\mathrm{CO}_{2}$ in the atmosphere. The Inland model is a dynamic vegetation model developed using IBIS (Integrated Biosphere Simulator, Foley et al., 1996) as core. However, the Inland model includes improvements on the representation of the biosphere-atmosphere interactions over South American biomes, with special emphasis on the Brazilian major crops, floodplain dynamics, and the transient land cover dynamics that characterize the Amazon and Cerrado regions.

Initially, two numerical experiments were performed for the present climate period. In the first experiment, this dynamic vegetation model was driven by the reanalysis data (Climate Forecast System Reanalysis - CFSR) (Saha et al. 2010). In a second experiment, the Inland model was forced with initial and boundary conditions provided by a regional climate model driven by the historical simulation of an Earth system global model (HadGEM2-ES). The use of these two data sets is important for assessing the response of the Inland surface flux with different input data, and for performing model validation. The nested regional-global simulations will be referred to as Eta-HadGEM2-ES. The modelling system used in this study is outlined as follows: the global model (HadGEM2-ES) provides the large-scale characteristics of flow to the Eta model which in turn provides more detailed atmospheric physical and dynamical processes for Inland model. Thus, the dynamic vegetation model simulates the dynamic behaviour of the land surface and the processes that occur in ecosystems and their consequences for the structure and composition of the physical and dynamical vegetation processes. The future projections of land surface changes were generated with Inland forced by Eta-HadGEM2-ES for RCP4.5 and RCP8.5 scenarios until 2100. In addition to the Eta-HadGEM2-ES forcing these runs used the RCP4.5 and RCP8.5 $\mathrm{CO}_{2}$ equivalent concentration curve, respectively.

In the following sections, the dynamic vegetation model will be described followed by Eta model, the global climate model, HadGEM2-ES, and the emissions scenarios, RCP4.5 and RCP8.5. In addition, the input data used to force the present climate simulations will also be discussed.

\section{The Models}

Initially, an overview of the models and parametrizations used in this work is presented. The models are based on physical principles. The confidence to provide quantitative estimates 
of future climatic change is increasing with improvements of resolution, computational methods, and parametrizations.

\section{Inland}

The Inland model was designed to represent the processes of the Earth's surface, with a primary focus on the representation of the Brazilian ecosystems and also of other parts of South America. The model is divided into four modules which operate on a common grid at different time steps.

The modules are: the land surface, vegetation phenology, carbon balance, and dynamic vegetation. The land surface module uses two surface layers of vegetation and six layers of soil to simulate the energy balance, water, carbon dioxide and when the surface. The module of vegetation phenology describes the behaviour of specific types of plants in response to seasonal climatic conditions. The carbon balance module simulates the gross photosynthesis, maintenance respiration, and growth respiration to represent the annual carbon balance for each plant functional types (PFTs). The dynamic vegetation module simulates the change of vegetation coverage resulting from changes in primary liquid yield, sequestration, biomass growth, mortality and biomass volume for each functional type of plant. Therefore, the Inland is capable of detecting changes in the vegetation structure and composition in response to environmental conditions. Thus, it is possible to perform simulations detecting the effects of changes in terrestrial carbon balance and of atmospheric $\mathrm{CO}_{2}$ on climate.

Initially, one of the 15 vegetation types is specified for each grid point for a given input. Thus, based on specific climatic variables, vegetation type for the tall and lower canopy is assigned using the distribution of one or more of the twelve PFTs (Table 1). At least one functional type of plant should exist in each grid point. The Inland model explicitly allows different PFTs in the same grid point that can compete for resources such as light, water, and nutrients. Thus, the Inland updates annually the vegetation type based on the distribution of the leaf area index (LAI) in each of the PFTs. For example, in an area where the predominant type is temperate broadleaf deciduous trees, if the simulated LAI value for the trees is high, medium or low, then the area will be designated as Temperate Deciduous Forest, Grassland and Savana, respectively. Therefore, a layer of taller vegetation is able to capture light first and shade the lower canopy vegetation. On the other hand, the lowest layer of vegetation captures soil moisture before the water percolates through the soil. Thus, the model can simulate the competition between trees and grasses.

Competition between PFTs within a layer of vegetation is governed by differences in the annual carbon balance resulting from different ecological strategies. This includes differences in phenology (evergreen vs. deciduous), and photosynthetic pathway (C3 or C4) (Foley et al. 1998). Therefore, the model comprises a generalized method for simulating the dynamic competition between types of plants in a single layer.

\section{Eta Model}

The regional climate model chosen to perform the downscaling of the global climate model simulation is the Eta model (Mesinger et al. 2012) This model was developed by the University of Belgrade (Mesinger et al. 1988). It has been used at CPTEC (Center for Weather Forecasts and Climate Studies) for weather forecast since 1996 (Chou 1996). The model was adapted to perform decadal mode integrations for studies of climate change scenarios by Pesquero et al. (2009) and Chou et al. (2012). Climate change scenarios were produced over South America for the future climate period taken from 2010-2100, for A1B emission scenario, with a resolution of $40 \mathrm{~km}$ and boundary conditions of the HadCM3 model (Marengo et al. 2012).

The Eta Model, nested in the HadGEM2-ES, was configured with $20-\mathrm{km}$ horizontal resolution and 38 layers in the vertical (Chou et al. 2014a). The model uses the eta vertical coordinate (Mesinger 1984). Model precipitation is produced by Betts-Miller-Janjic cumulus parameterization scheme (Janjić 1994) and by the Zhao cloud microphysics scheme (Zhao et al. 1997). The land-surface transfer processes are parameterized by the NOAH scheme (Chen $e t$ al. 1997; Ek et al. 2003). The radiation scheme package was developed by the Geophysical Fluid Dynamics Laboratory. The scheme includes short-wave (Lacis and Hansen 1974) and long-wave radiation (Fels and Schwarzkopf 1975). The radiation tendencies are recalculated every $1 \mathrm{~h}$ and are applied every time step. $\mathrm{CO}_{2}$ equivalent concentrations followed the

Table 1. Plant Functional Types

\begin{tabular}{ll}
\hline PFTs & Description \\
\hline 1 & tropical broadleaf evergreen trees \\
2 & tropical broadleaf drought-deciduous trees \\
3 & warm-temperate broadleaf evergreen trees \\
4 & temperate conifer evergreen trees \\
5 & temperate broadleaf cold-deciduous trees \\
6 & boreal conifer evergreen trees \\
7 & boreal broadleaf cold-deciduous trees \\
8 & boreal conifer cold-deciduous trees \\
9 & evergreen shrubs \\
10 & cold-deciduous shrubs \\
11 & C4 grasses \\
12 & C3 grasses \\
\hline
\end{tabular}


RCP4.5 and RCP8.5 are updated every 3 years since 2005. The atmospheric turbulence scheme has the turbulent kinetic energy as prognostic variable. Monin-Obukhov similarity theory combined with Paulson stability functions (Paulson 1970) are applied at the surface layer. A more detailed description and recent developments of the Eta Model can be found in Mesinger et al. (2012).

\section{Climate Change Scenarios and HadGEM2-ES model}

The lateral boundary conditions used to drive the Eta regional model were supplied by the Earth System configuration of the UK Met Office Hadley Centre Global Environmental Model, version 2, the HadGEM2-ES (Collins et al. 2011; Jones et al. 2011). This global model was used in the 5th Coupled Model Intercomparison Project (CMIP5) forced by all RCPs scenarios. In this work, we use the RCP 4.5 and RCP8.5 runs of HadGEM2-ES. In RCP4.5 scenario the radiative forcing increases almost linearly up to about 2060 and then slows down the increase rate until the end of the century where it stabilizes. The RCP8.5 is characterized by a continuous increasing greenhouse gas emission which continues beyond 2100 .

The HadGEM2-ES climate model comprises an atmospheric GCM at N96 and L38 horizontal and vertical resolutions, and an ocean GCM with a 1-degree horizontal resolution (increasing to $1 / 3$ degree at the equator) and 40 vertical levels. Earth system components included are the terrestrial and ocean carbon cycle and tropospheric chemistry. Terrestrial vegetation and carbon is represented by the dynamic global vegetation model, TRIFFID (Cox 2001). This scheme simulates the coverage and carbon balance of 5 vegetation types: broadleaf tree, needleleaf tree, C3 grass, C4 grass and shrub, in addition to bare soil. It considers fractions of urban areas, lakes and ice prescribed from the IGBP land cover map (Loveland et al. 2000). Ocean biology and carbonate chemistry are modelled by diat-HadOCC which comprises limitation of plankton growth by macro- and micronutrients, and representations of the silicate and dissolved iron cycles, as well as a DMS (dimethyl sulphide) sub-model for cloud feedback. Tropospheric chemistry is represented by the UKCA model, and also includes new aerosol species (organic carbon and dust).

\section{Input atmospheric data}

In order to provide a better understanding of the sensitivity of the Inland Model to the input data and validate the Inland outputs, the model was executed with two data sets: the CFSR reanalyses for the period between 1981 and 2005, and the Eta-HadGEM2-ES simulations, for the period between 1961 and 2005. The comparison of the atmospheric variables from these two dataset helps to understand the response of one of the Inland simulations with respect to the other simulation.
The Eta-HadGEM2-ES simulations have been evaluated against observations by Chou et al. (2014a).

Figures 1 compare temperature, precipitation, cloud cover, and specific humidity output from Eta-HadGEM2ES against CFSR reanalyses. These are the atmospheric variables used as input to the Inland model. This figure shows averages for January and June, and for the period 1981-2005. These variables are input to Inland model at daily frequency. The months are chosen as representative of opposite precipitation regimes in the Amazon region. The differences in temperature and precipitation mean fields between the two datasets are generally small in terms of the spatial pattern. In general, Eta-HadGEM2-ES simulation is colder than CFSR reanalyses in the central part of the continent and over tropical Atlantic Ocean (Figure 1A-D). In June in Central Brazil, the Eta-HadGEM2-ES mean precipitation shows higher values than CFSR (Figure $1 \mathrm{G}, \mathrm{H}$ ). In both months, the Intertropical Convergence Zone (ITCZ) over the Atlantic Ocean is better defined as a band in the reanalyses. In January, precipitation in the reanalysis data is excessive, showing values over $12 \mathrm{~mm} /$ day over the central southern Amazon (Figure 1F), while in the Eta-HadGEM2ES precipitation does not exceed $9 \mathrm{~mm} /$ day (Figure 1E). Silva et al. (2011) have shown that CFSR overestimates precipitation in this region. Actually, the Eta simulated precipitation agrees closer to the CRU observations (Chou et al. 2014a). Similar to precipitation field, CFSR data presents greater values of cloud cover over central southern Amazon than the Eta-HadGEM2-ES simulation in January (Figure 1I,J). On the other hand, in June over the Amazon, these two data sets show close similarities with one another (Figure 1K,L). It should be remarked that CFSR cloud cover is a model 6-h mean product. The mean specific humidity shows more disagreement between Eta and CFSR. For this variable, the major differences is over the Andes Mountains in both months and over the Amazon in January. The CFSR data shows less humidity over the Andes and more humidity over the Amazon than the Eta-HadGEM2-ES simulations in both months (Figure 1M-P).

Another Inland input data is the initial vegetation type (Ramankutty and Foley 1999; SAGE 2002). The tropical evergreen forest area covers the central part of South America, surrounded by some areas of Savanna in south-eastern and dense shrubland in southern. These vegetation types are represented by a combination of 12 plant functional types (Table 1) distributed in two canopy layers. The Inland model applies climatic constrains to determine the PFT in each grid cell (Foley et al. 1996). The initial vegetation map is shown in the Results section for comparison with future vegetation cover. The input in terms of soil texture was derived from Carter and Scholes (2000). 

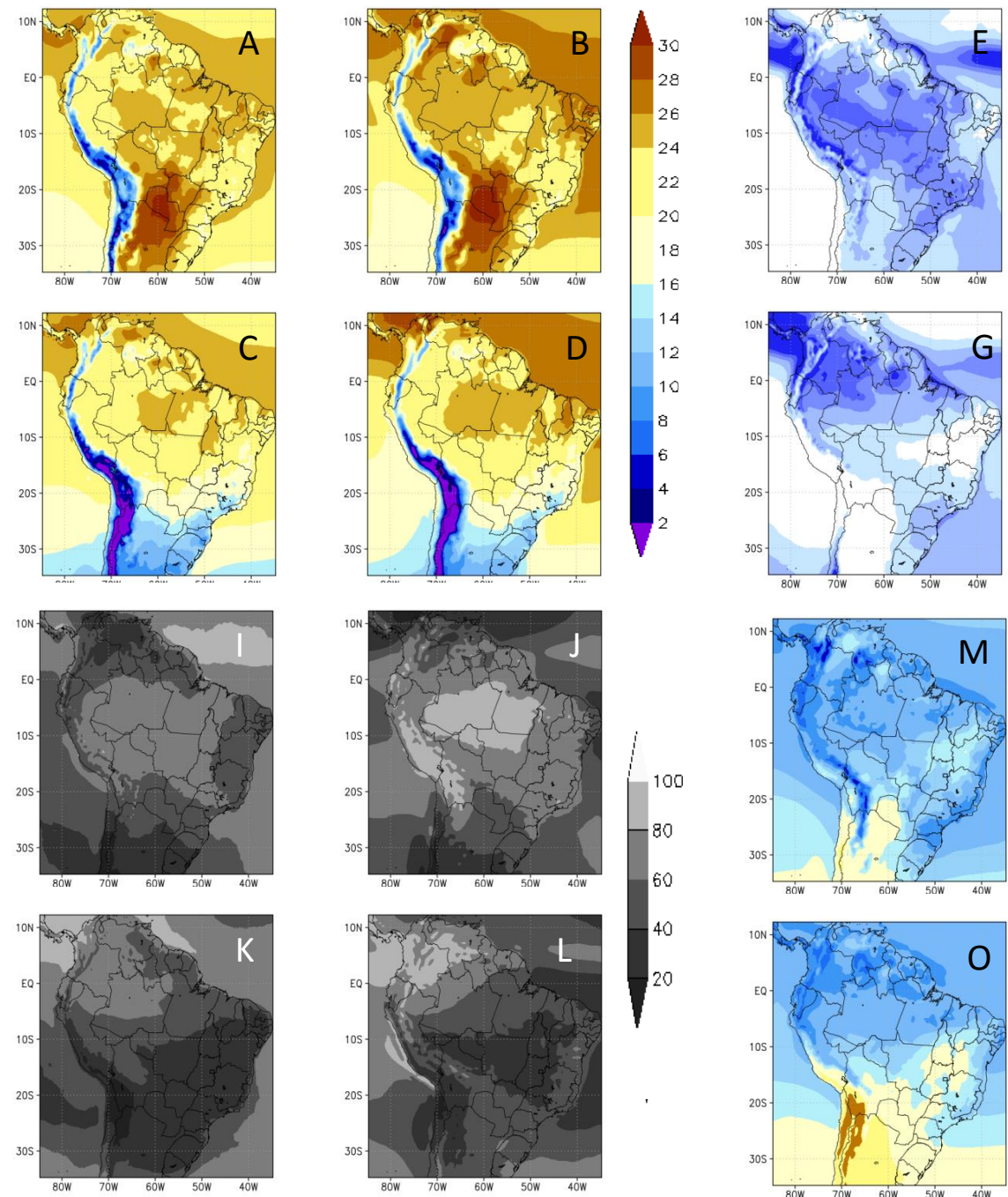
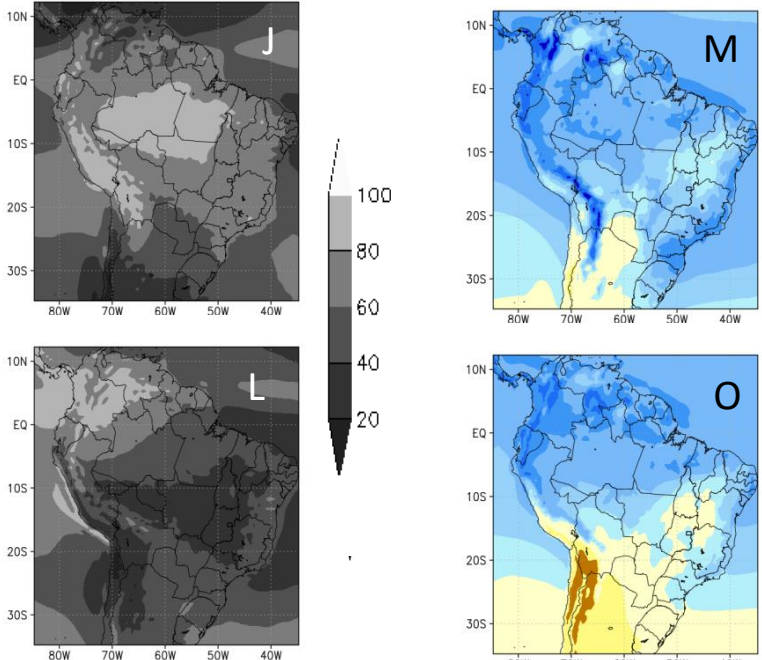

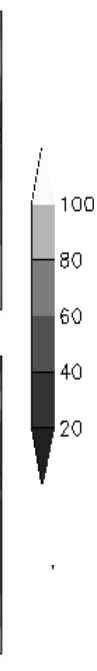

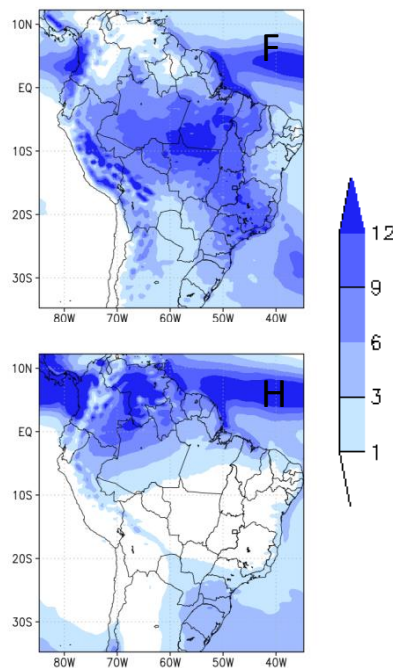

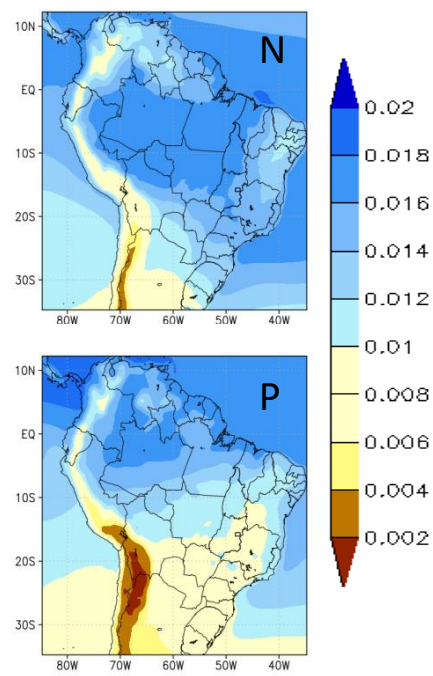

Figure 1. January (top) and June (bottom) mean temperature $\left({ }^{\circ} \mathrm{C}\right)(\mathrm{A}-\mathrm{D})$, precipitation $\left(\mathrm{mm}\right.$ day $\left.{ }^{-1}\right)(\mathrm{E}-\mathrm{H})$, cloud cover $(\%)(\mathrm{I}-\mathrm{L})$, and specific humidity $\left(\mathrm{g} \mathrm{kg} \mathrm{g}^{-1}\right)$ (M-P) simulated by Eta-HadGEM2-ES (left column) and of CFSR reanalyses (right column) for 1981-2005 period. This figure is in color in the electronic version.

\section{Flux tower measurements}

Data of the LBA Model Intercomparison Project (LBAMIP) tower (Santarém-k83) (da Rocha et al. 2004) located at Tapajos National Forest, in Santarem-PA, Brazil, were used to validate the Inland simulations. This tower, situated in a tropical humid forest, has an annual total precipitation above $1900 \mathrm{~mm}$ and a dry season shorter than 4 months (da Rocha 2009). Latent heat flux and sensible heat flux measurements for the period between 1st. January 2002 and 31st January 2004 were provided at hourly frequency.

\section{RESULTS}

The Inland model validation is carried out using the Santarém flux tower measurements, and it is based on the analysis of the mean diurnal cycle and some statistical metrics such as mean square error (RMSE), linear correlation and standard deviation. Taking into account model errors, we will assess the impact of future climate change on the forest biome under the RCP4.5 and the RCP8.5 scenarios.

\section{Validation}

Figure 2 shows the 30-year average of the diurnal cycle of the sensible and latent heat fluxes for hourly tower observations data of Santarem-K83 and for the Inland simulations driven by both CFSR (Inland-CFSR) and EtaHadGEM2-ES (Inland-EtaHad). Both Inland simulations represent reasonably well the diurnal cycle of the fluxes. In June, the Inland simulations forced by Eta-HadGEM2-ES, however, underestimate the amplitude of latent heat fluxes (Figure 2C) which shows some differences between the two simulations. The sensible heat fluxes show underestimation 
in January in both simulations (Figure 2A), while in June the Inland simulations driven by CFSR and Eta-HadGEM2-ES exhibit a maximum displacement in an hour earlier (Figure 2B). In addition, underestimate of fluxes is found in both months at the hours immediately after sunset. Table 2 presents the root mean square error (RMSE), the correlation of the mean diurnal cycle and the standard deviation of the two simulations. These statistics were calculated from the 30year mean diurnal cycle. Despite the differences between the simulations, satisfactory correlations and RMSE values are obtained, in particular for Inland-EtaHad simulations.

\section{Impact on Amazon Biome}

Figure 3 shows the distribution of the predominant vegetation types in the Inland model domain for the present climate and for the two future periods: middle of the century (2055 to 2065) and end of the century (2085 to 2095), in both RCP4.5 and RCP8.5 scenarios. Some areas of rainforest in the Amazon region are replaced by deciduous forest type and grassland in RCP4.5 scenario and only by grassland in RCP8.5 scenario at the end of the century (Figure 3D and $3 \mathrm{E}$, respectively). Although part of this area is currently being considered as the arc of deforestation, the study shows that changes in biomes would progress to the interior of the Amazon region in both scenarios.

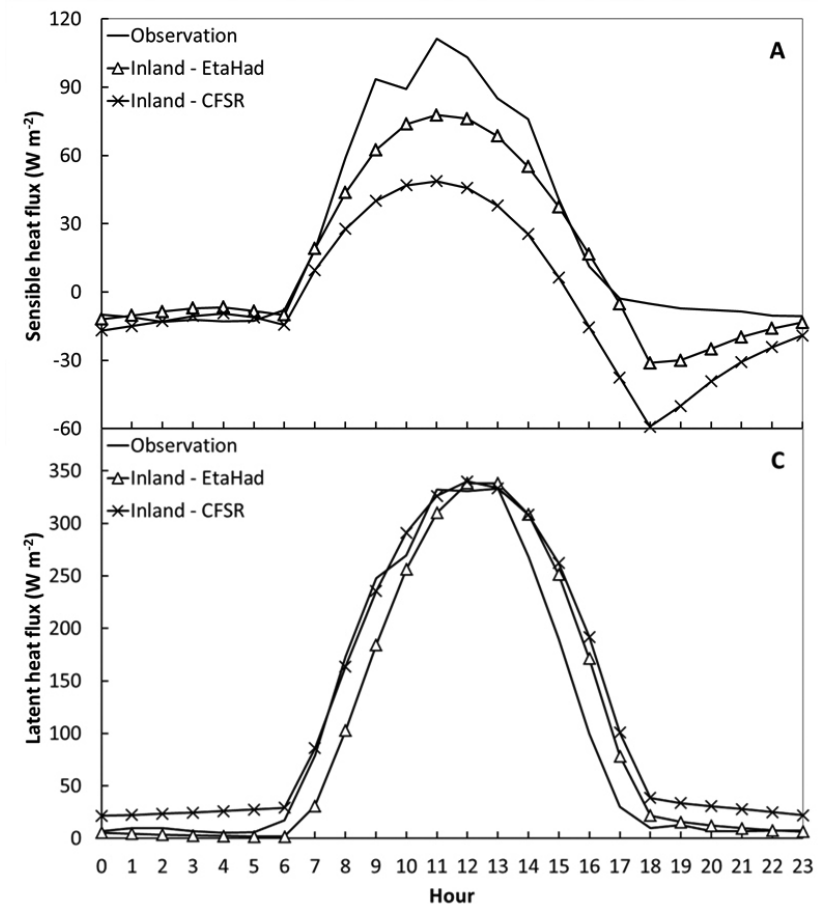

Table 3 shows the percentage of occurrence of the predominant vegetation types in the Brazilian states of Northern Region namely: Amazonas, Pará, Rondônia, Roraima, Amapá, Acre, and Tocantins (Figure 3A). Mato Grosso State was added to the study area as the arc of deforestation crosses this state. The location of the states on the map is shown in Figure 3A. The Amazon forest areas reduce as simulations approach the end of the century and change the scenario from RCP4.5 to RCP 8.5. The model indicates a reduction of approximately $9 \%$ in the area of tropical forest in the RCP4.5 scenario and a further reduction in the RCP8.5 scenario of about $50 \%$ in the Amazonas State at the end of the century. In some states like Pará, Rondônia, and Acre, the reduction of forest areas is greater than $90 \%$ in the most pessimistic scenario in the 2085 2095 period. The states of Mato Grosso and Tocantins show $100 \%$ grassland cover by the end of the century, however, both areas did not have high forest cover percentage at the initial time. The impacts are distinguished for each state because the information obtained here aims at supporting adaptation or mitigation studies and measures, which should be taken by local governmental actions.

Figure 4 shows the changes in the sensible and latent heat fluxes for Santarem k83 site projected by the Inland model for a wet (January) and a dry (June) month. In January (Figure 4C), the latent heat flux decreases substantially during the day in relation to the present climate latent heat flux. This reduction

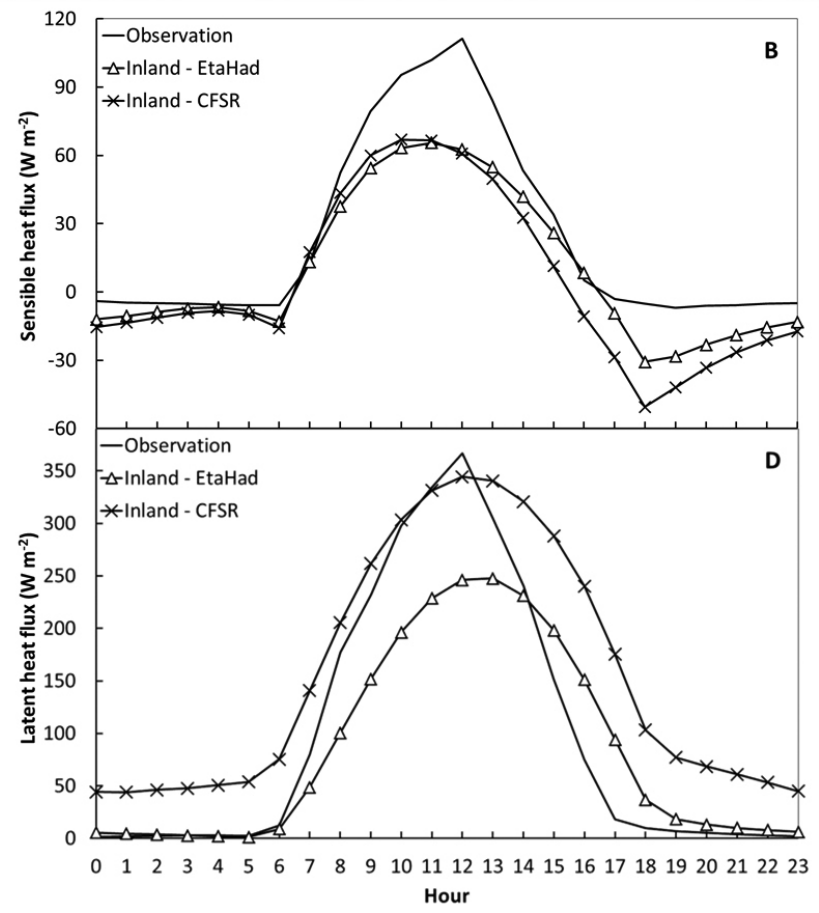

Figure 2. Mean diurnal cycle of sensible heat flux ( $\left.\mathrm{W} \mathrm{m}^{-2}\right)\left(\mathrm{A}\right.$ and $\mathrm{B}$ ) and latent heat flux ( $\left.\mathrm{W} \mathrm{m}^{-2}\right)$ (C and D) of observation (no symbol), Inland-EtaHad (triangle) and Inland-CFSR (cross) for January (left) and June (right) at Santarém-k83. 
of the latent heat flux is more evident in the scenario RCP8.5. On the other hand, the sensible heat flux increases, during daytime, between $07 \mathrm{am}$ to $16 \mathrm{pm}$. Only minor changes occur in June in the future climate. The increase in the sensible heat flux responds to the increase of $\mathrm{CO}_{2}$ concentration and to the increase of temperature of up to $3^{\circ} \mathrm{C}$ in the period 2071-2098 in RCP4.5, and increase of up to $6^{\circ} \mathrm{C}$ in RCP8 8 scenario (Figure 5). Figure 6 shows the reduction of precipitation over Amazonia, which can affect the soil moisture availability and, consequently, decrease the latent heat flux. Most of the net radiation is used for heating the soil, thereby increasing the sensible heat flux.

The leaf area index (LAI) and the net primary production (NPP) of each PFT depends on the quantity of carbon absorbed by the vegetation during the year. Therefore, these are good parameters to indicate the impact of climate change in the rainforest biome. Figure 7 shows the 5 -year mean variation of LAI and NPP for the PFTs that exist in the nine grid points surrounding the Santarem-k83 site. A 5-year average was applied to the time series to reduce the interannual variability signal and to show more clearly the trend. The linear negative trends of LAI and NPP in tropical broadleaf evergreen trees and tropical broadleaf drought-deciduous trees in both scenarios have statistical significance of $99,9 \%$. The RCP 8.5 scenario has a more pronounced decreasing trend than RCP4.5 scenario. However, for the functional type of warm (c4) grasses, increasing trend has statistical significance of $99,9 \%$ in the RCP4.5 and no statistical significance in the RCP8.5 scenario. The decrease of LAI and NPP in forest PFTs is due to the neutralization of $\mathrm{CO}_{2}$ fertilization effect caused by reduced rainfall (Figure 6) and soil humidity simulated by the Eta-HadGEM2-ES in this area.

\section{DISCUSSION}

The Inland validation shows that the model can reproduce the surfaces fluxes over a forest biome in different months using reanalysis data as well as Eta model simulation. The model projects clear impacts on the sensible and latent heat fluxes in both scenarios. Increase in sensible heat flux is consistent with the changes in energy partition due to precipitation reduction. The significant reduction of latent heat flux in RCP8.5 is also related to the changes in the surface cover type.
The most significant result of this study is the changes in the spatial distribution of biomes over northern Brazilian States. In both RCP scenarios, forest was replaced by grassland, which advanced toward the interior of the Amazon region. According to Costa and Pires (2010), this vegetation replacement could increase the dry season duration. In addition, intense droughts, which could cause damage to vegetation, can persist during longer periods leading to even more severe drought (Saatchi et al. 2013).
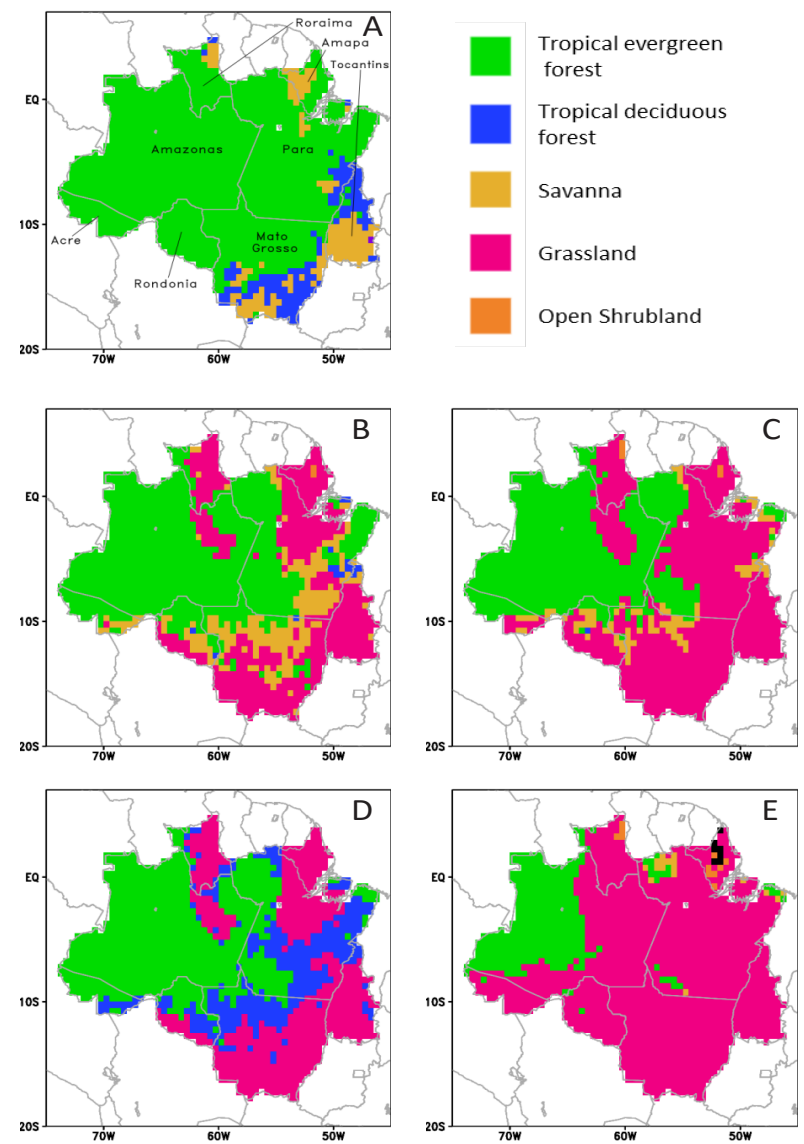

Figure 3. Initial (A), RCP4.5 middle of the century (B), RCP8.5 middle of the century (C), RCP4.5 end of the century (D) and RCP8.5 end of the century (E) vegetation type. This figure is in color in the electronic version.

Table 2. Root mean square error, correlation and the standard deviation $\left(\mathrm{W} \mathrm{m}^{-2}\right)$ of sensible and latent heat fluxes for the mean diurnal cycle in January and June against Santarém-K83 tower.

\begin{tabular}{lllllll}
\hline January & \multicolumn{3}{l}{ Sensible heat flux } & \multicolumn{4}{l}{ Latent heat flux } \\
\hline & RMSE & Correlation & S. Deviation & RMSE & Correlation & S. Deviation \\
\hline Inland-EtaHad & 15.59 & 0.97 & 37.50 & 32.56 & 0.96 & 128.15 \\
Inland-CFSR & 33.80 & 0.90 & 31.84 & 32.83 & 0.98 & 124.27 \\
\hline June & Sensible heat flux & & \multicolumn{2}{l}{ Latent heat flux } & \\
\hline & RMSE & Correlation & S. Deviation & RMSE & Correlation & S. Deviation \\
\hline Inland-EtaHad & 18.93 & 0.97 & 32.33 & 52.99 & 0.93 & 72.49 \\
Inland-CFSR & 23.63 & 0.94 & 36.44 & 72.49 & 0.94 & 116.71 \\
\hline
\end{tabular}


Table 3.Projected occurrence of predominant vegetation type in each Brazilian states.

\begin{tabular}{|c|c|c|c|c|c|}
\hline & Initial & RCP4.5 & & RCP8.5 & \\
\hline & & 2055 to 2065 & 2085 to 2095 & 2055 to 2065 & 2085 to 2095 \\
\hline \multicolumn{6}{|l|}{ Amazonas } \\
\hline Trop. evergreen forest & 100.0 & 93.8 & 91.0 & 89.6 & 50.0 \\
\hline Trop. deciduous forest & 0.0 & 0.0 & 2.5 & 0.0 & 0.0 \\
\hline Savanna & 0.0 & 0.4 & 0.0 & 0.8 & 0.0 \\
\hline Grassland & 0.0 & 5.9 & 6.4 & 9.6 & 50.0 \\
\hline Open shrubland & 0.0 & 0.0 & 0.0 & 0.0 & 0.0 \\
\hline \multicolumn{6}{|l|}{ Pará } \\
\hline Trop. evergreen forest & 91.2 & 51.8 & 32.1 & 30.1 & 5.3 \\
\hline Trop. deciduous forest & 4.5 & 2.3 & 39.1 & 0.0 & 0.0 \\
\hline Savanna & 4.3 & 18.7 & 0.0 & 6.8 & 4.3 \\
\hline Grassland & 0.0 & 27.3 & 28.8 & 63.1 & 90.4 \\
\hline Open shrubland & 0.0 & 0.0 & 0.0 & 0.0 & 0.0 \\
\hline \multicolumn{6}{|l|}{ Rondônia } \\
\hline Trop. evergreen forest & 100.0 & 46.2 & 42.3 & 20.5 & 2.6 \\
\hline Trop. deciduous forest & 0.0 & 2.6 & 29.5 & 1.3 & 0.0 \\
\hline Savanna & 0.0 & 24.4 & 0.0 & 21.8 & 0.0 \\
\hline Grassland & 0.0 & 26.9 & 28.2 & 56.4 & 97.4 \\
\hline Open shrubland & 0.0 & 0.0 & 0.0 & 0.0 & 0.0 \\
\hline \multicolumn{6}{|l|}{ Roraima } \\
\hline Trop. evergreen forest & 83.8 & 28.4 & 14.9 & 20.3 & 8.1 \\
\hline Trop. deciduous forest & 4.1 & 0.0 & 16.2 & 0.0 & 0.0 \\
\hline Savanna & 12.2 & 5.4 & 0.0 & 0.0 & 0.0 \\
\hline Grassland & 0.0 & 66.2 & 68.9 & 75.7 & 86.5 \\
\hline Open shrubland & 0.0 & 0.0 & 0.0 & 4.1 & 5.4 \\
\hline \multicolumn{6}{|l|}{ Amapá } \\
\hline Trop. evergreen forest & 63.0 & 0.0 & 0.0 & 0.0 & 0.0 \\
\hline Trop. deciduous forest & 0.0 & 0.0 & 2.2 & 0.0 & 0.0 \\
\hline Savanna & 37.0 & 0.0 & 0.0 & 0.0 & 0.0 \\
\hline Grassland & 0.0 & 95.7 & 97.8 & 95.7 & 69.6 \\
\hline Open shrubland & 0.0 & 4.3 & 0.0 & 4.3 & 15.2 \\
\hline \multicolumn{6}{|l|}{ Acre } \\
\hline Trop. evergreen forest & 100.0 & 78.0 & 76.0 & 62.0 & 6.0 \\
\hline Trop. deciduous forest & 0.0 & 0.0 & 24.0 & 0.0 & 0.0 \\
\hline Savanna & 0.0 & 20.0 & 0.0 & 12.0 & 0.0 \\
\hline Grassland & 0.0 & 2.0 & 0.0 & 26.0 & 94.0 \\
\hline Open shrubland & 0.0 & 0.0 & 0.0 & 0.0 & 0.0 \\
\hline \multicolumn{6}{|l|}{ Tocantins } \\
\hline Trop. evergreen forest & 6.7 & 0.0 & 0.0 & 0.0 & 0.0 \\
\hline Trop. deciduous forest & 36.7 & 3.3 & 13.3 & 0.0 & 0.0 \\
\hline Savanna & 55.6 & 7.8 & 0.0 & 4.4 & 0.0 \\
\hline Grassland & 0.0 & 88.9 & 86.7 & 95.6 & 100.0 \\
\hline Open shrubland & 0.0 & 0.0 & 0.0 & 0.0 & 0.0 \\
\hline \multicolumn{6}{|l|}{ MatoGrosso } \\
\hline Trop. evergreen forest & 58.9 & 16.1 & 6.6 & 4.3 & 0.0 \\
\hline Trop. deciduous forest & 25.3 & 0.3 & 27.3 & 0.0 & 0.0 \\
\hline Savanna & 15.8 & 30.3 & 0.0 & 10.9 & 0.0 \\
\hline Grassland & 0.0 & 53.3 & 66.1 & 84.9 & 100.0 \\
\hline Open shrubland & 0.0 & 0.0 & 0.0 & 0.0 & 0.0 \\
\hline
\end{tabular}



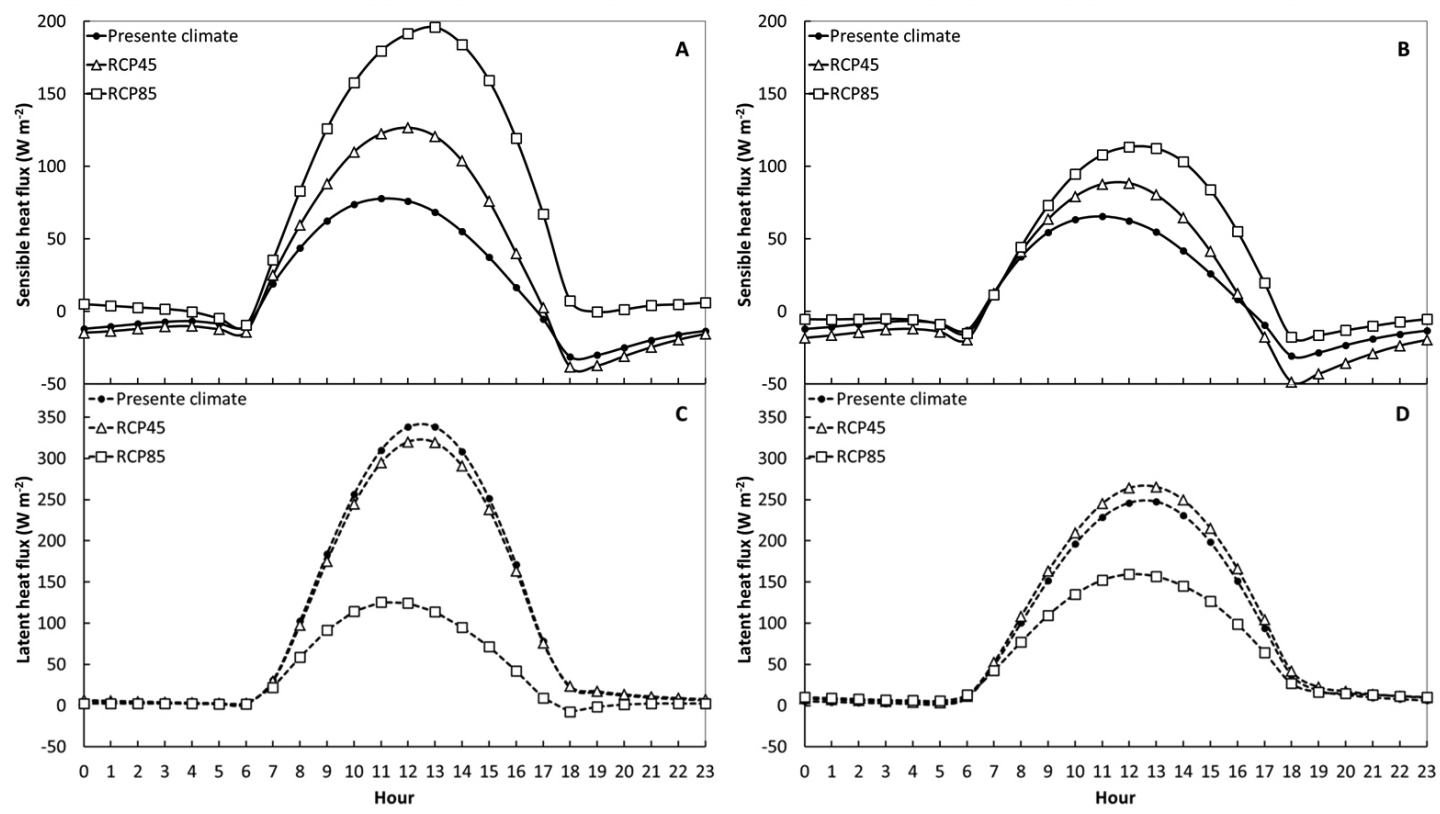

Figure 4. Mean diurnal cycle of sensible heat flux ( $\left.\mathrm{W} \mathrm{m}^{-2}\right)\left(\mathrm{A}\right.$ and $\mathrm{B}$ ) and latent heat flux ( $\left.\mathrm{W} \mathrm{m} \mathrm{m}^{-2}\right)(\mathrm{C}$ and $\mathrm{D})$ of Inland Eta present climate (circle), Inland-EtaHadRCP4.5 future climate (triangle) and Inland-EtaHadRCP85 future climate (square) for January (left) and June (right) at Santarém-k83 station corresponding model grid point. The period considered for the present climate was from 1981 until 2005 and for the future climate was from 2071 until 2098.

The Eta-HadGEM2-ES projections show increase of the consecutive dry days in the region toward the end of the century in both scenarios (Chou et al. 2014b), which may have favoured the vegetation replacement in these simulations.

Although the increase of atmospheric $\mathrm{CO}_{2}$ concentration may favour the growth of trees by direct effect on photosynthesis (Norby et al. 2005) and water use efficiency (Field et al. 2008), the projections of Eta-HadGEM2-ES in both RCP scenarios show temperature increase and rainfall decrease over Santarem-k83 area in the last 30 years of the $21^{\text {st }}$ century. This result agrees partially with other works that show a warmer and drier environment for the region, which could convert some part of the Amazon rainforest into a savanna type of vegetation (Salazar et al. 2007; Oyama and Nobre 2003). The major role of temperature increase as a driver of the Amazon forest reduction is suggested by Galbraith el al. (2010).

The changes in LAI and NPP that are projected for the future indicate a reduction in the amount of $\mathrm{CO}_{2}$ absorbed by the forest over Santarém-k83. The NPP reduction is due to both soil moisture limitations on photosynthesis, and the increase in maintenance of respiration costs (Cox et al. 1999). Physiologically, the photosynthesis should increase forest productivity; however, this process is offset by the inhibitory effects of higher temperatures and lower soil moisture (Lloyd and Farquhar 2008). Tropical forest carbon sink exists as a consequence of the net primary productivity. Field measurements (Baker et al. 2004) demonstrate a significant carbon increase in forest plots across Amazonia which suggests that old-grown tropical forests are gaining in biomass. However, changes in vegetation type may have important implications to the carbon cycle and biodiversity within these forests. Lapola et al. (2009) highlighted that if, in the future, either $\mathrm{CO}_{2}$ fertilization does not play any important role on tropical forests or the dry season is longer than 4 months, then there can be replacement of large portions of the Amazon forest by tropical savanna.

Some uncertainties should be taken into account. These uncertainties are primarily due to the climate projections and the assumed future emission scenarios. Our framework does not consider human interventions such as land use conversions. Another aspect not treated in this study of dryer and warmer future climate is the frequency and intensity of fires that can increase the forest mortality. However, these results can warn about the potential magnitude of the impacts of climate change on the rainforest biome.

\section{CONCLUSIONS}

The simulations from the dynamic vegetation model are found adequate for long-term integrations and for the study of the earth system climate-biosphere feedbacks 

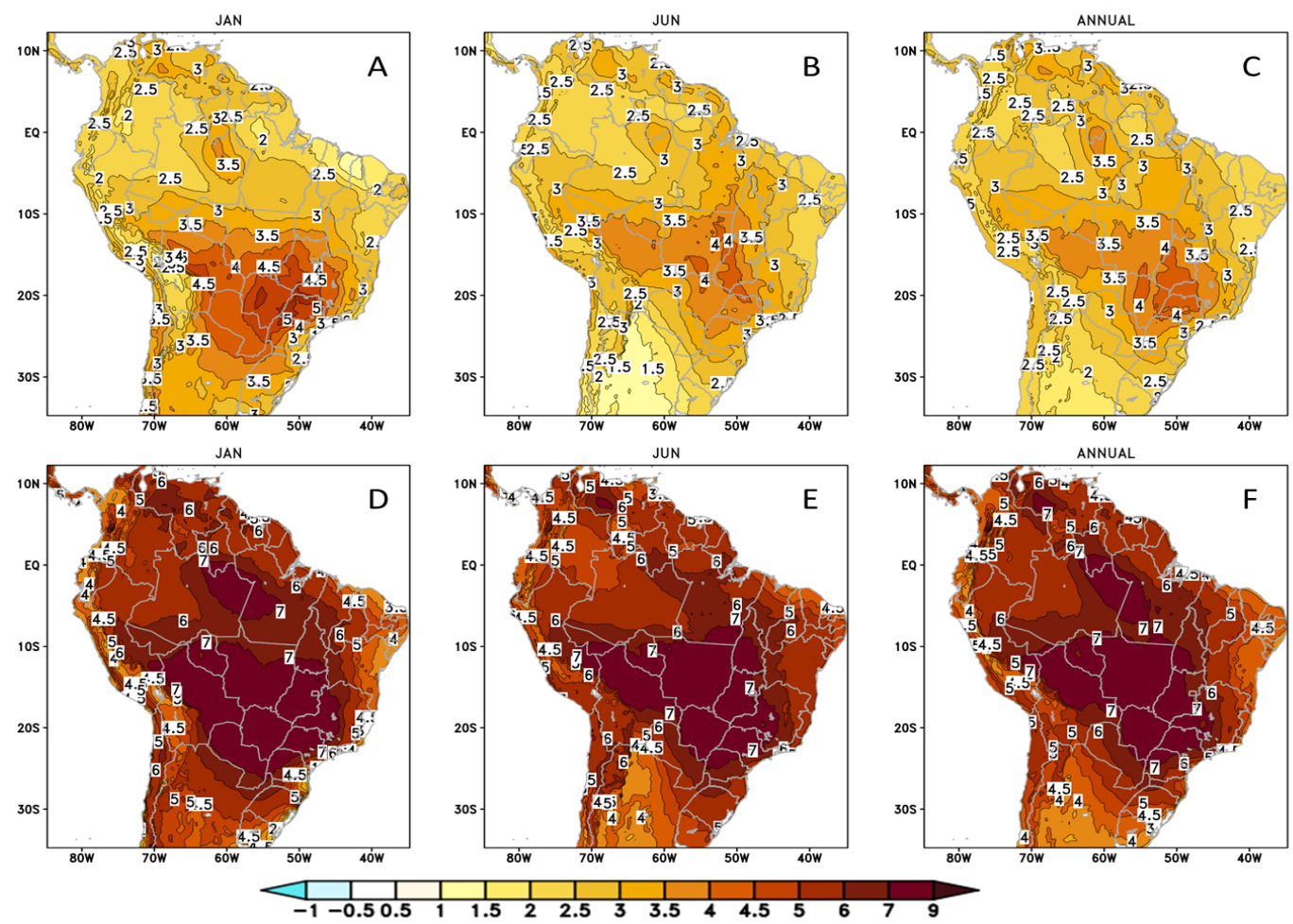

Figure 5. Difference between the baseline (1981-2005) and the future (2071-2098) annual mean temperature $\left({ }^{\circ} \mathrm{C}\right)$ simulated by the Eta-HadGEM2 model for the RCP4.5 January (A), June (B) and annual (C) means, and for RCP8.5 January (D), June (E) and annual (F) means. This figure is in color in the electronic version.
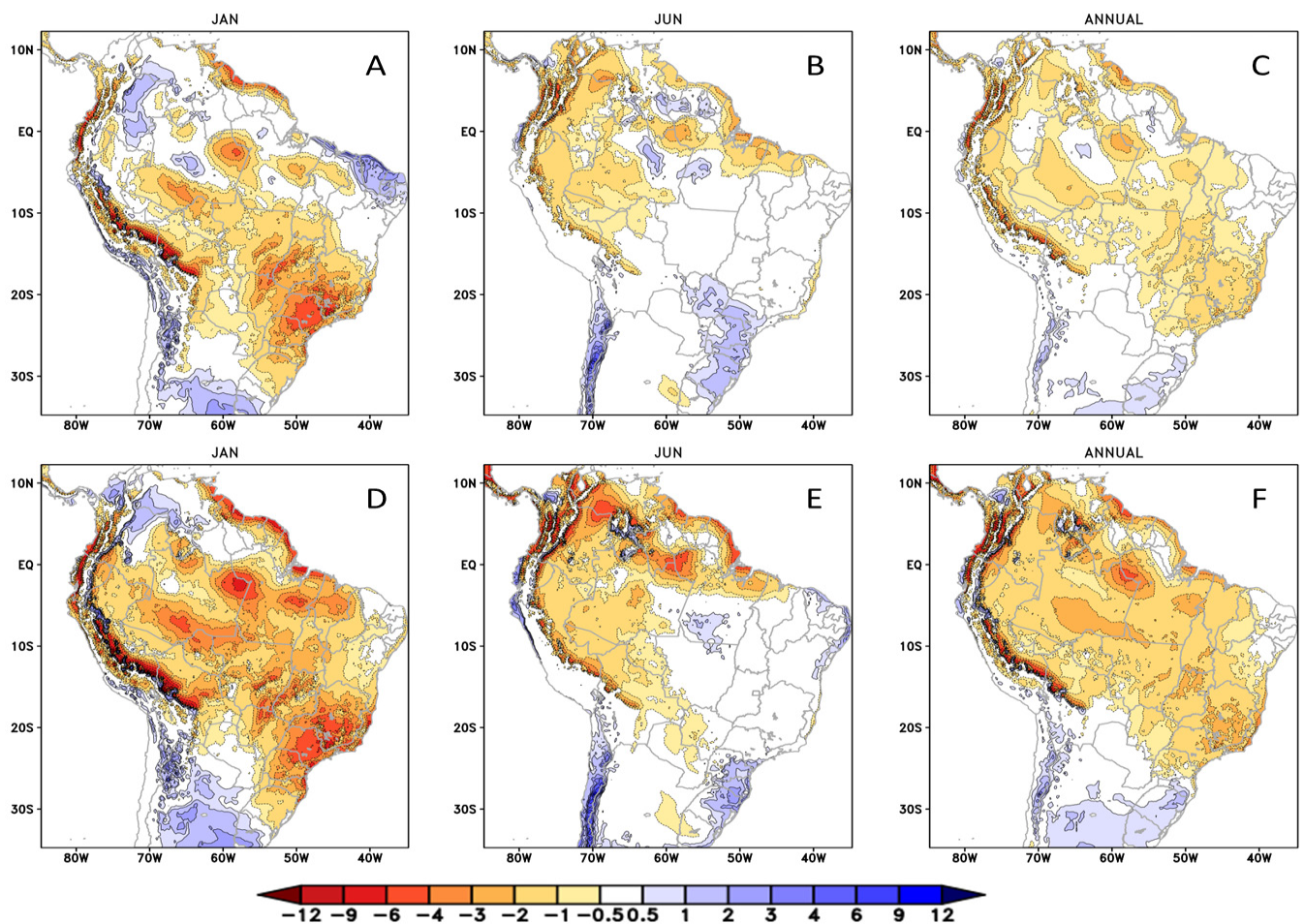

Figure 6. Difference between the baseline (1981-2005) and the future (2071-2098) annual mean precipitation (mm) simulated by the Eta-HadGEM2 model for the RCP4.5 January (A), June (B) and annual (C) means, and for RCP8.5 January (D), June (E) and annual (F) means. This figure is in color in the electronic version. 

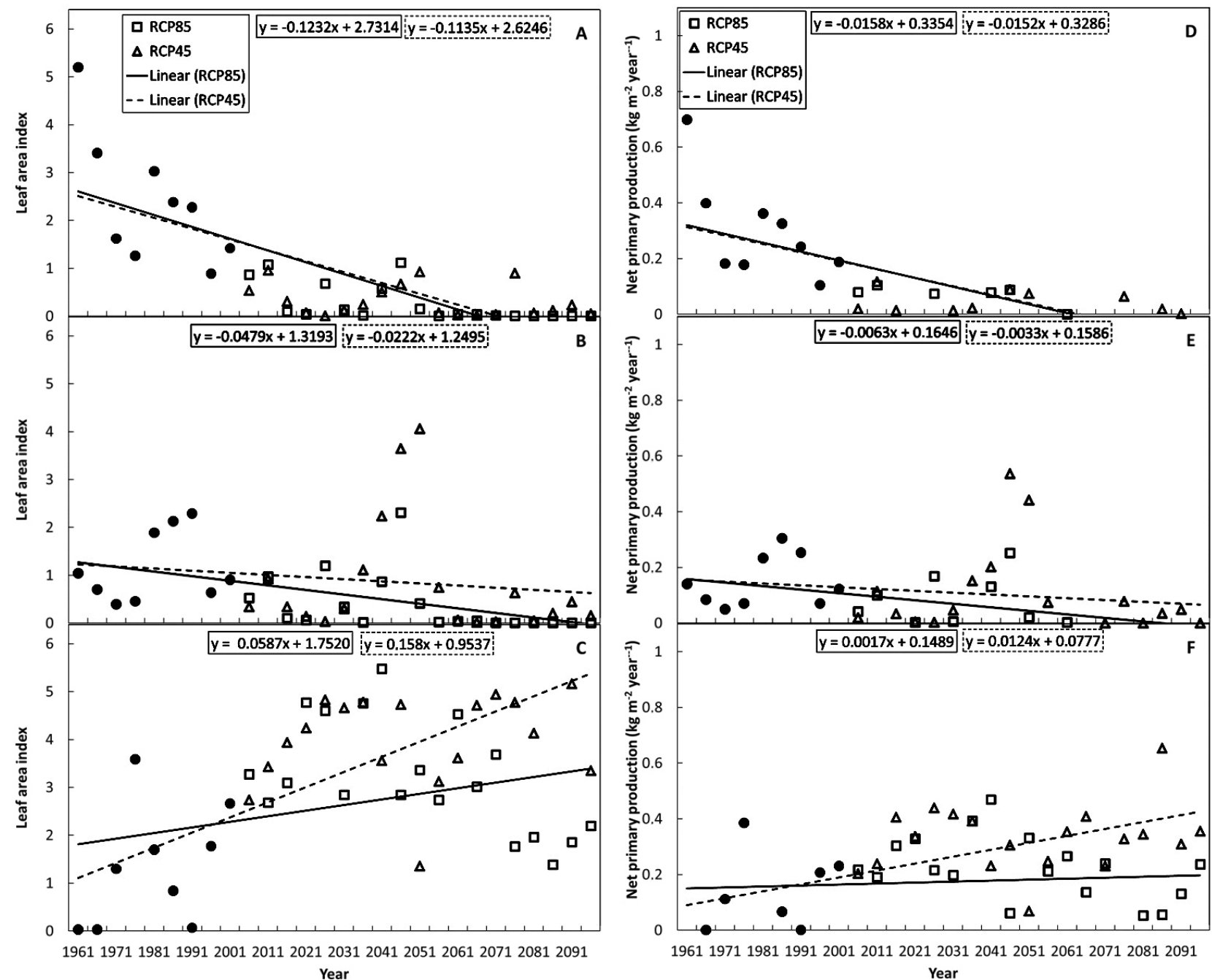

Figure 7. 5-year mean leaf area index (no dimension) (A-C) and net primary production ( $\left.\mathrm{kg} \mathrm{m}^{-2} \mathrm{year}^{-1}\right)$ (D-F) for: tropical broadleaf evergreen trees (top), tropical broadleaf drought-deciduous trees (center), and warm C4 grasses (bottom). The symbols indicate the present climate (circles), RCP4.5 (triangles) and RCP8.5 (squares) and lines are tendency for RCP4.5 (dashed) and for RCP8.5 (solid).

and their implications at regional scale. The results shown here agree with other studies but it must be clarified that they are model dependent and they refer to the system Inland-Eta-HadGEM2-ES. The simulations show that climate change may create environment conditions never before experienced by the forest biome. Whether these climate change impacts on the biome are combined with effects of Amazon deforestation or not, still, these results can suggest a substantial destruction of the Amazon tropical forest. This Amazon biome reduction can lead to a positive feedback of temperature increase and affect the regional hydrological cycle. Studies with a fully coupled Eta and Inland models can improve the representation of the climate-vegetation interactions.

\section{ACKNOWLEDGMENTS}

Thanks to BADC (Martin Juckes) for the GCM boundary conditions. Thanks to the programs: CIAT, MCTI (through UNDP BRA/10/G32), CAPES, and CNPq (308035/2013-5 and 457874/2014-7) for partially funding the long-term integrations.

\section{REFERENCES}

Baker, T.R.; Phillips, O.L.; Malhi, Y.; Almeida, S.; Arroyo, L., Di Fiore, A.; et al. 2004. Increasing biomass in Amazonian forest plots. Philosophical Transactions of the Royal Society of London Series B-Biological Sciences, 359: 353-365.

Betts, R.A.; Cox, P.M.; Collins, M.; Harris, P.P.; Huntingford, C.; Jones, C.D. 2004. The role of ecosystem-atmosphere interactions in simulated Amazonian precipitation decrease and forest 
dieback under global climate warming. Theoretical and Applied Climatology, 78: 157-175.

Carter, A.J.; Scholes, R.J. 2000. SoilData v2.0: Generating a Global Database of Soil Properties. Available on: Global Soil Data Products, CD-ROM (IGBP-DIS), USDA, CSIR, IGBP-DIS, FAO and ISRIC, IGBP Data and Information Services, Postdam.

Chen, F.; Janjic, Z.; Mitchell, K. 1997. Impact of atmospheric surface-layer parameterizations in the new land-surface scheme of the NCEP mesoscale Eta model. Boundary-Layer Meteorology, 85: 391-421.

Chou, S.C. 1996. Modelo Regional Eta. In: Climanálise Especial, Ediçáo Comemorativa de 10 anos, p.203-207.

Chou, S.C.; Marengo, J.A.; Lyra, A.; Sueiro, G.; Pesquero, J.; Alves, L.M.; et al. 2012 Downscaling of South America Present Climate Driven by 4-Member HadCM3 Runs. Climate Dynamics, 38: 635-653.

Chou, S.C.; Lyra, A.A.; Mourão, C.; Dereczynski, C.; Pilotto, I.; Gomes, J.; et al. 2014a. Evaluation of the Eta Simulations Nested in Three Global Climate Models. American Journal of Climate Change, 3: 438-454.

Chou, S.C.; Lyra, A.A.; Mourão, C.; Dereczynski, C.; Pilotto, I.; Gomes, J.; et al. 2014b. Assessment of Climate Change over South America under RCP 4.5 and 8.5 Downscaling Scenarios. American Journal of Climate Change, 3: 512-527.

Collins, W.J.; Bellouin, N.; Doutriaux-Boucher, M.; Gedney, N.; Halloran, P.; Hinton, T.; et al. 2011. Development and evaluation of an Earth-System model-HadGEM2. Geoscientific Model Development, 4: 1051-1075.

Costa, M.H.; Pires, G.F. 2010. Effects of Amazon and Central Brazil deforestation scenarios on the duration of the dry season in the arc of deforestation. International Journal of Climatology, 30: 1970-1979.

Cox, P.M.; Betts, R.A.; Bunton, C.; Essery, R.L.H.; Rowntree, P.R.; Smith, J. 1999. The impact of new land surface physics on the GCM simulation of climate and climate sensitivity. Climate Dynamics, 15: 183-203.

Cox, P.M. 2001. Description of the TRIFFID Dynamic Global Vegetation Model Hadley Centre, Met Office, Technical Note 24.

Cox, P.M.; Betts, R.A.; Collins, M.; Harris, P.P.; Huntingford, C.; Jones C.D. 2004. Amazonian forest dieback under climatecarbon cycle projections for the 21 st century. Theoretical and Applied Climatology, 78: 137-156.

da Rocha, H.R.; Goulden, M.L.; Miller, S.D.; Menton, M.C.; Pinto, L.D.V.O; Freitas, H.C; et al. 2004. Seasonality of water and heat fluxes over a tropical forest in eastern Amazonia. Ecological Applications, 14: 22-32.

da Rocha, H.R.; Manzi, A.O.; Cabral, O.M.; Miller, S.D.; Goulden, M.L.; Saleska, S.R.; et al. 2009. Patterns of water and heat flux across a biome gradient from tropical forest to savanna in Brazil. Journal of Geophysical Research, 114: 1-8.

Ek, M.; Mitchell, K.E.; Lin, Y.; Rogers, E.; Grunmann, P.; Koren, V.; et al. 2003. Implementation of Noah Land Surface Model Advances in the National Centers for Environmental Prediction
Operational Mesoscale Eta Model. Journal of Geophysical Research, 108: 8851.

Fels, S.B.; Schwarzkopf, M.D. 1975. The Simplified Exchange Approximation: A New Method for Radiative Transfer Calculations. Journal of the Atmospheric Sciences, 32: 1475-1488.

Field, C.B.; Jackson, R.B.; Mooney, H.A. 2008: Stomatal responses to increased $\mathrm{CO}_{2}$-Implications from the plant to the global scale. Plant Cell and Environment, 18: 1214-1225.

Foley, J.; Prentice, I.; Ramankutty, N.; Levis, S.; Pollard, D.; Sitch, S.; Haxeltine, A. 1996. An integrated biosphere model of land surface processes, terrestrial carbon balance, and vegetation dynamics. Global Biogeochemical Cycles, 10: 603-628.

Foley, J.A.; Levis, S; Prentice, I.C. 1998. Coupling dynamic models of climate and vegetation. Global Change Biology, 4: 561-79.

Galbraith, D.; Levy, P.E.; Sitch, S.; Huntingford, C.; Williams, M.; Meir. P. 2010. Multiple mechanisms of Amazonian forest biomass losses in three dynamic global vegetation models under climate change. New Phytologist, 187: 647-665.

Good, P.; Jones, C.; Lowe, J.; Betts, R.; Booth, B.; Huntingford, C. 2011. Quantifying Environmental Drivers of Future Tropical Forest Extent. Journal of Climate, 24: 1337-1349.

Hutyra, L.R.; Munger, J.W.; Nobre, C.A.; Saleska, S.R.; Vieira, S.A.; Wofsky, S.C. 2005. Climatic variability and vegetation vulnerability in Amazônia, Geophysical Research Letter, 32: L24712.

IPCC, 2007. Climate Change 2007: Impacts, Adaptation and Vulnerability. In: Parry, M.L.; Canziani, O.F.; Palutikof, J.P.; van der Linden, P.J.; Hanson, C.E. (Ed.). Contribution of Working Group II to the Fourth Assessment Report of the Intergovernmental Panel on Climate Change, Cambridge University Press, Cambridge, UK, 976pp.

Janjić, Z.I. 1994. The step-mountain eta coordinate model: further developments of the convection, viscous sublayer and turbulence closure schemes. Monthly Weather Review, 122: 927-945.

Jones, C.D.; Hughes, J.K.; Bellouin, N.; Hardiman, S.C.; Jones, G.S.; Knight, J.; et al. 2011. The HadGEM2-ES implementation of CMIP5 centennial simulations. Geoscientific Model Development, 4: 543-570.

Kirschbaum, M; Fischin, A. 1996. Climate change impacts on forests. In: Watson, R.; Zinyowera, M.C.; Moss, R.H. (Ed.). Climate change 1995: impacts, adaptation and mitigation of climate change: scientific-technical analysis. Cambridge University Press, Cambridge, UK, p.95-129.

Lacis, A.A.; Hansen, J. 1974. A Parameterization for the Absorption of Solar Radiation in the Earth's Atmosphere. Journal of the Atmospheric Sciences, 31: 118-133.

Lapola, D.M.; Oyama, M.D.; Nobre C.A. 2009. Exploring the range of climate biome projections for tropical South America: The role of $\mathrm{CO}_{2}$ fertilization and seasonality. Global Biogeochemical Cycles, 23: GB3003.

Lloyd, J.; Farquhar, G.D. 2008. Effects of rising temperatures and $\left[\mathrm{CO}_{2}\right]$ on the physiology of tropical forest trees. Philosophical Transactions of the Royal Society B: Biological Sciences, 363: 1811-1817. 
Loveland, T.R.; Reed, B.C.; Brown, J.F.; Ohlen, D.O.; Zhu, Z.; Yang, L.; et al. 2000. Development of a global land cover characteristics database and IGBP DISCover from $1 \mathrm{~km}$ AVHRR data. International Journal of Remote Sensing, 21: 1303-1330.

Marengo, J.A.; Chou, S.C.; Kay, G.; Alves, L.M.; Pesquero, J.F.; Soares, W.R.; et al. 2012. Development of regional future climate change scenarios in South America using the Eta CPTEC/ HadCM3 climate change projections: climatology and regional analyses for the Amazon, São Francisco and the Parana River Basins. Climate Dynamics, 38: 1829-1848.

Miles, L.; Grainger, A.; Phillips, O. 2004. The impact of global climate change on tropical biodiversity in Amazonia. Global Ecology and Biogeography, 13: 553-565.

Mesinger, F. 1984. A blocking technique for representation of mountains in atmospheric models. Rivista di Meteorologia Aeronautica, 44: 195-202.

Mesinger, F.; Janjic, Z.I.; Nickovic, S.; Gavrilov, D.; Deaven D.G. 1988. The step-mountain coordinate: model description, and performance for cases of Alpine lee cyclogenesis and for a case of an Appalachian redevelopment. Monthly Weather Review, 116: 1493-1518.

Mesinger, F.; Chou, S.C.; Gomes, J.L.; Jovic, D.; Bastos, P.; Bustamante, J.F.; et al. 2012. An upgraded version of the Eta Model. Meteorology and Atmospheric Physics, 116: 63-79.

Norby, R.J.; DeLucia, E.H.; Gielen, B.; Calfapietra, C.; Giardina, C. P.; King, J. S.; et al. 2005. Forest response to elevated $\mathrm{CO}_{2}$ is conserved across a broad range of productivity. Proceedings of the National Academy of Sciences of the United States of America, 102: 18052-18056.

Oyama, M.D.; Nobre, C.A. 2003. A new climate-vegetation equilibrium state for Tropical South América. Geophysical Research Letters, 30: 2199-2203.

Paulson, C.A. 1970. The mathematical representation of wind speed and temperature profiles in the unstable atmospheric surface layer. Journal of Applied Meteorology, 9: 857-861.

Pesquero, J.F.; Chou, S.C.; Nobre, C.A.; Marengo, J.A. 2009. Climate downscaling over South America for 1961-1970 using the Eta Model. Theoretical and Applied Climatology, 99: 75-93.
Ramankutty, N.; Foley, J. A. 1999. Estimating historical changes in global land cover: Croplands from 1700 to 1992. Global Biogeochemical Cycles, 13: 997-1027.

Saatchi, S.; Asefi-Najafabady, S.; Malhi Y.; Aragão, L.E.O.C.; Anderson, L.O.; Myneni, R.B.; Nemani, R.. 2013. Persistent effects of a severe drought on Amazonian forest canopy. Proceedings of the National Academy of Sciences of the United States of America, 110: 565-570.

Saha, S.; Moorthi, S.; Pan, H.L.; Wu, X.; Wang, J.; Nadiga, S.; et al. 2010. The NCEP climate forecast system reanalysis. Bulletin of the American Meteorological Society, 91: 1015-1057.

SAGE, 2002. Atlas of the Biosphere. (http://www.sage.wisc.edu/atlas/ maps. php? datasetid $=25$ includerelatedlinks $=1 \&$ dataset $=25$ ). Access on 14/05/2015.

Salazar, L.F.; Nobre, C.A.; Oyama, M.D. 2007. Climatic change consequences on the biome distribution in tropical South America. Geophysical Research Letters, 34: L09708.

Settele, J.; Scholes, R.; Betts, R.; Bunn, S.; Leadley, P.; Nepstad, D.; et al. 2014. Terrestrial and inland water systems. In: Field, C.B.; Barros, V.R.; Dokken, D.J.; Mach, K.J.; Mastrandrea, M.D.; Bilir, T.E.; et al. (Ed.). Climate Change 2014: Impacts, Adaptation, and Vulnerability. Part A: Global and Sectoral Aspects. Cambridge University Press, Cambridge, United Kingdom and New York, NY, USA, p. 271-359.

Silva, V.B.; Kousky, V.E.; Higgins, R.W. 2011. Daily precipitation statistics for South America: An intercomparison between NCEP reanalyses and observations. Journal of Hydrometeorology 12: 101-117.

Zhao, Q.; Black, T.L.; Baldwin, M.E. 1997 Implementation of the Cloud Prediction Scheme in the Eta Model at NCEP. Weather and Forecasting, 12: 697-712.

Recebido em 05/06/2015

Aceito em 13/11/2015 
